Egypt. Acad. J. biolog. Sci., Vol. 5 (1) 7-18 (2013) C. Physiology \& Molecular Biology Email: egyptianacademic@yahoo.com

Received: 12/4/2013

ISSN: 2090-0767

www.eajbs.eg.net

\title{
Hepatitis B and C Viruses incidence, the Risk Factors of Hepatocellular Carcinoma, is low in Aseer Region, Saudi Arabia
}

\author{
Ali Alshehri \\ Biology Department, Faculty of Science, King Khalid University, Abha, P.O Box \\ 9004, Saudi Arabia. \\ Corresponding author: Ali Alshehri, Ph.D \\ eMail: ali_50_50@yahoo.com \\ Address: Biology Department, Faculty of Science, King Khalid University, Abha, P.O \\ Box 9004, Saudi Arabia.
}

\begin{abstract}
Aim: Risks of hepatocellular carcinoma (HCC) following hepatitis B (HBV) and/or hepatitis $\mathrm{C}$ virus (HCV) infection are well known. The aim of this study was to determine the prevalence and risk factors of hepatitis B and $\mathrm{C}$ virus infections in blood donors at Aseer Region, Saudi Arabia

Methods: The study was conducted on random blood samples collected from healthy blood donor volunteers, who were referred to Blood Transfusion Centers found at Aseer region, during the period March 2012 to February 2013. All the collected blood units were screened for hepatitis B surface antigen (HBsAg), anti-HBc, HCV, human immunodeficiency virus (HIV) 1 and 2, human T-cell lymphotropic virus (HTLV) I/II, venereal disease research laboratory (VDRL) and malaria. All donated blood were checked for HBV-DNA, HCV-RNA and HIV-RNA by nucleic acid test (NAT) technology.

Results: Of 7267 (26 (0.36\%) females and 7241 (99.64) males) blood donors screened, with median age of 28 (female) and 30 years (males), 71 (0.98\%) were HBsAg positive of them 66 (0.91) were positive to HBV-DNA, 449 (6.18\%) were anti-HBc positive of them 78 (1.07\%) were positive to HBV-DNA. Cases positive to both HBsAg and HBc-Ab were 69 (0.95\%) all of them were positive to HBV-DNA. There were $5(0.069 \%)$ cases positive for HCV, none of them showed mixed infection with HVB. All positive cases for HBsAg, HBc-Ab and HCV were shown to be among male volunteers.

Conclusion: Prevalence of HCV in Asser region is very low. In the time that HBsAg is low, prevalence of $\mathrm{HBcAb}$ is relatively moderate. Expected incidence of heptatocellular carcinoma due to infection with HCV is much lower than HBV.
\end{abstract}

Key words: Blood donors, HBV, HBsAg, HCV, HCC, CLD, Saudi Arabia

\section{INTRODUCTION}

Chronic liver disease is responsible for over 1.4 million deaths annually and is characterized by permanent inflammatory processes that predispose to liver cancer and in particular hepatocellular carcinoma (HCC) (Ayele and Gebre-Selassie, 2013). In healthy liver, inflammatory processes stimulate growth and repair and restore normal liver architecture. Chronic liver disease
(CLD) results from an inflammatory injury to the liver, which has persisted for six or more months without complete resolution. Chronic liver disease comprises of a spectrum of disease such as chronic hepatitis, liver cirrhosis, and HCC (Laraba et al., 2010). In CLD, the balance of damage versus regeneration in the liver is disrupted and can lead to the formation of excessive scar tissue, termed fibrosis. In the long-term, an 
exacerbation of fibrosis will lead to cirrhosis, which is characterized by abnormal liver architecture and function and is associated with a significant reduction in overall health and wellbeing. At cirrhotic stages, liver damage is often irreversible or difficult to treat. Cirrhosis leads frequently to death from liver failure or to HCC (Bartosch, 2010). Indeed, HCC is the first cause of death in cirrhotic patients (Parkin et al., 2001), and is a tumor with poor prognosis, ranking third in terms of death by cancer. Furthermore, it is the fifth most prevalent cancer worldwide, with 800,000 new cases per year in the world (Parkin et al., 2001, El-Serag, 2007).

Hepatitis B virus (HBV) and hepatitis $\mathrm{C}$ virus (HCV) infections are primarily hepatropic. Chronic infection with these viruses causes progressive liver disease and HCC (Beasley et al., 1981; Simonetti et al., 1989; Colombo et al., 1989; Bruix et al., 1989; Lauer and Walker, 2001; Ferrari et al., 2003 ), and $\mathrm{HBV} / \mathrm{HCV}$ co-infection further increases the risk of HCC (Shi et al., 2005). Also HBV and HCV have been shown to be lymphotropic (Pasquinelli et al., Ferri 1993; et al., Pawlotsky 1995). Some studies have examined the role of these infections in non-Hodgkin's lymphoma (NHL) but the findings were inconclusive (Kuniyoshi et al., 2001; Negri et al., 2001). HCV infection has been shown to be associated with other malignant diseases such as multiple myeloma and thyroid cancer (Montella et al., 2001).

Hepatocellular carcinoma is the sixth most common cancer and the third most common cause of mortality from cancer worldwide (Parkin et al., 2002). Hepatitis B virus and HCV monoinfections are well-known major risk factors for HCC, and the relative importance varies worldwide and changes over time (Lu et al., 2006). Because of their shared modes of transmission, coinfection of $\mathrm{HBV}$ and $\mathrm{HCV}$ is not uncommon, particularly in countries with a high prevalence of HBV or HCV. Hepatitis B virus and HCV coinfection results in more severe liver disease (Sato et al., 1994) and in an increased risk of HCC (Zarski et al., 1998) than monoinfection.

The epidemiology of liver cancer is linked to the incidence and mortality rates from liver cirrhosis, since a large proportion of HCCs develop from cirrhotic liver (London and McGlynn, 2006). The improved survival and reduced mortality from cirrhosis, due to improvements in the prevention and treatment of this condition, have in fact increased the possibility of developing HCC in cirrhotic patients. Of some importance are also the improvements in diagnosis, mainly due to widespread use of ultrasound and measurement of alphafetoprotein since the early 1980s, which led to more frequent detection of neoplastic liver in cirrhotic patients (ShuChun et al., 2009).

$\mathrm{HCV}$ is a single-stranded RNA virus of the flavivirus family, about 9.5 $\mathrm{kb}$ in length. HCV does not integrate into the host genome, and the means by which it establishes chronic infection are unknown. The association of chronic HCV infection with development of HCC is well-established; this nearly always occurs in the presence of cirrhosis. It is estimated that approximately $80 \%$ of persons infected with HCV will develop a chronic infection, and 15-20\% will develop serious liver disease, often many decades later. Among those who develop cirrhosis, $1-4 \%$ per year will develop HCC. Several important cofactors, such as alcohol consumption and older age at infection, are known to affect the probability of developing HCC among persons chronically infected with HCV (Ikeda et al., 1993; Tsukuma et al., 1993; Lauer and Walker, 2001). 
HBV is a small, partially doublestranded DNA virus of the hepadnavirus family, which replicates through a reverse transcription phase. Unlike $\mathrm{HCV}$, HBV integrates into the host hepatocyte genome early in infection, usually at sites of DNA damage (Bill and Summers, 2004). The virus carries no known oncogenes, and sites of integration are not consistent from cell to cell. But the presence of multiple integrated viral genes is thought to create genomic instability in the host and may lead to loss of heterozygosity for tumor suppressor genes. Moreover, hepatitis B $\mathrm{x}$ antigen acts as a transactivator that may lead to increased transcriptional activity of cellular oncogenes as well as interference with the function of tumor suppressor genes, such as p53 (Feitelson et al., 2002). In populations where HBV infection occurs in early childhood, the lifetime risk of HCC in an HBV-infected person has been estimated at $27 \%$ for males and 4\% for females. (Dickinson et al., 2002). Among endemic populations, however, there may be substantial disparities in HCC risk due to differences in the natural history of chronic HBV infection between populations (Evans et al., 1998).

\section{MATERIALS AND METHODS I. Study population}

The study was conducted on random blood samples collected from healthy blood donor volunteers, who were referred to Blood Transfusion Centers found at Aseer region (Southern part of KSA), during the period March 2012 to January 2013. According to routine practice, volunteer blood donors were interviewed (history of intravenous drug abuse, jaundice, admission to fever hospital and history of HBV vaccination) and medically examined before donation. Those with high-risk behaviors including intravenous drugs abusers, history of promiscuous sexual relationships, homosexuals, homeless or those with any medical problem especially jaundice or hospitalization at fever hospitals, bleeding disorders necessitating component transfusion, pregnancy or recent delivery less than 12 weeks were rejected.

Sera of the 7267 (26 females and 7261 males) collected samples were separated and kept at $-80^{\circ} \mathrm{C}$ till use.

\section{II- Viral Markers screening:}

Hepatitis B virus surface antigen (HBsAg) test:

Detection of HBsAg was done using commercially available Monolisa $^{\mathrm{TM}}$ HBsAg ULTRA ELISA kit (BIO-RAD, Mames-la-Coquette, France) for the detection of HBsAg in serum and plasma.

\section{Confirmatory test for HBsAg positive units:}

Blood units which were shown to be HBsAg positive or at border line were retested using HBsAg confirmation kit (DIA.PRO Diagnostic, Milano, Italy), a set of reagents for the confirmation of HBsAg positivity in human sera or plasma.

\section{Anti-Hepatitis B core antigen antibodies (HBcAb) test:}

Detection of HBcAb was done using commercially available Monolisa $^{\mathrm{TM}}$ Anti-HBc PLUS ELISA kit (BIO-RAD), a detection kit for antibodies to nucleocapsid antigen (core) of the HBV in human serum or plasma by enzyme immunoassay.

Confirmatory test for $\mathrm{HBcAb}$ positive units:

Blood units which were positive or at border line to $\mathrm{HBcAb}$ were retested using anti-HBc detection kit (total, DIA.PRO) which is Enzyme immunoassay for the detection of antibodies to hepatitis $B$ core antigen (anti-HBc) in human serum or plasma.

\section{Anti-Hepatitis C virus antibodies (HCV-Ab) test:}

Detection HCV-Ab was done using the commercially available Murex anti-HCV $4^{\text {th }}$ generation (DiaSorin, S. P. A. 
UK Branch, Central road, Dartfod DA1 5Lr, UK), an enzyme immunoassay for the detection of antibodies to hepatitis $\mathrm{C}$ virus in human serum or plasma.

\section{Confirmatory test for Anti-HCV-Ab:}

Positive and borderline HCV-Ab units were confirmed using the commercially available $\mathrm{HCV}$ confirmation kit (DIA.PRO), an enzyme immunoassay for the confirmation of HCV Ab positivity in human sera or plasma.

\section{Nucleic acid test (NAT)}

All samples were tested for the presence of HBV, HCV and HIV nucleic acids by NAT using Roche COBAS ${ }^{\circledR}$ TaqScreen MPX Test which is a qualitative multiplex test that enables simultaneous screening of HIV-1 Group $M$ and Group O RNA, HIV-2 RNA, HCV RNA and HBV DNA in pooled and individual plasma donations.

Statistical analysis
The biochemical data recorded were expressed as mean $\pm \mathrm{SD}$ and statistical and correlation analyses were undertaken using the One-way ANOVA followed by a post-hoc LSD (Least Significant Difference) test. A P value < 0.05 was statistically significant. A Statistical analysis was performed with the Statistical Package for the Social Sciences for Windows (SPSS, version 10.0, Chicago, IL, USA).

\section{RESULTS \\ I. Donor selection and sample Collection:}

Both donor selection and blood testing were done according to WHO and Saudi Ministry of Health recommendations.

The studied samples included 7267 (26 (0.36\% females; 7241 (99.64\%) randomly selected blood donations from donors with a median age of 28 and 30 years respectively (Table 1 ).

Table 1: Gender distribution among blood donors accepted for donation.

\begin{tabular}{cccc}
\hline Gender & Number & $\%$ & Median age \\
\hline Female & 26 & 0.35778 & 28 \\
Male & 7241 & 99.6422 & 30 \\
\hline Total & 7267 & 100 & 30 \\
\hline
\end{tabular}

Donors of ages between 21 and proportion (50.59\%, $P \leq 0.001$ ) with a 30 years constituted the largest median age of 26 years (Table 2).

Table 2: Number and age rage distribution among blood donors accepted for donation.

\begin{tabular}{clrcc}
\hline Age range & \multicolumn{1}{c}{ Number } & $\%$ & Median & Variance \\
\hline $18-20$ & 429 & 5.903 & 20 & 0.649317 \\
$21-30$ & 3676 & 50.585 & 26 & 7.722881 \\
$31-40$ & 2203 & 30.315 & 35 & 7.967831 \\
$41-50$ & 786 & 10.816 & 45 & 8.186748 \\
$51-60$ & 173 & 2.381 & 55 & 8.828577 \\
\hline Total & 7267 & 100 & 30 & \\
\hline
\end{tabular}

Table 3 lists the distribution of the nationalities of the study participants. Blood donors were mostly Saudi nationals (95.13\%). Non-Saudi donors were Afghani, Bengali, Egyptians, Eritrean, Indians, Filipinos, Jordanians, Lebanese, Pakistanis, Palestinians,
Sudanese, Turkish and Yemenis. The higher non-Saudi proportion was Yemenis (1.58\%), followed by Egyptians (1.32\%), Sudanese $(0.37 \%)$, Pakistani (0.35\%), Indians (0.30\%), Syrian (0.29\%) and then Jordanians (0.27\%). 
Table 3: Nationality distribution blood donors accepted for donation.

\begin{tabular}{lrr}
\hline Nationality & Number & \% \\
\hline Afghani & 2 & 0.0275 \\
\hline Bengali & 5 & 0.0688 \\
\hline Egyptian & 96 & 1.3210 \\
\hline Erytrian & 3 & 0.0413 \\
\hline Indian & 22 & 0.3027 \\
\hline Jordon & 20 & 0.2752 \\
\hline Lebanese & 1 & 0.0138 \\
\hline Pakistani & 26 & 0.3578 \\
\hline Philippine & 5 & 0.0688 \\
\hline Palastine & 7 & 0.0963 \\
\hline Saudi & 6913 & 95.1287 \\
\hline Sudanese & 27 & 0.3715 \\
\hline Syrian & 21 & 0.2891 \\
\hline Tyrkey & 4 & 0.0550 \\
\hline Yemani & 115 & 1.5825 \\
\hline Total & 7267 & 100.0000 \\
\hline & &
\end{tabular}

II- Routine screening:

Hepatitis B virus surface antigen (HBsAg) test:

Detection of hepatitis B surface antigen (HBsAg) was done using commercially available ELISA kit. Of the 7267 donated blood, 71 (0.098\%) case were positive to HBsAg (Table 4). There were no infection detected among volunteers in age range 18-20. The highest infection rate inside groups was in age ranges $41-50$ (3.05\%) and 51-60 (2.89\%) and was lowest in age range 21$30(0.52 \%)$.

Table 4: Age range of HBsAg positive among blood donors accepted for donation.

\begin{tabular}{crrrrr}
\hline Age range & Number & $\begin{array}{c}\text { \% in total } \\
\text { population }\end{array}$ & $\begin{array}{c}\text { HBsAg } \\
\text { positive } \\
\text { (n) }\end{array}$ & $\begin{array}{c}\text { \% infection } \\
\text { in total } \\
\text { population }\end{array}$ & $\begin{array}{c}\text { \% infection } \\
\text { inside the } \\
\text { age group }\end{array}$ \\
\hline $18-20$ & 429 & 5.903 & 0 & 0 & 0 \\
$21-30$ & 3676 & 50.585 & 19 & 0.2615 & 0.5169 \\
$31-40$ & 2203 & 30.315 & 23 & 0.3165 & 1.0440 \\
$41-50$ & 786 & 10.816 & 24 & 0.3303 & 3.0534 \\
$51-60$ & 173 & 2.381 & 5 & 0.0689 & 2.8902 \\
\hline Total & 7267 & 100 & 71 & 0.9770 & 0.9770 \\
\hline
\end{tabular}

Of the $69 \mathrm{HBsAg}$ positive donors there were one case coinfected with HIV, $70(0.96 \%)$ of positive to antibody to

core antigen (HBcAb) and $66(0.91 \%)$ were positive to HBV-DNA (Table 5).

Table 5: Other markers associated with HBsAg positive blood donors accepted for donation.

\begin{tabular}{|l|c|c|c|c|c|c|c|}
\hline Positive to & HBsAg & HBcAb & HCV & HIV & RPR & HTLV & NAT \\
\hline HBsAg & 71 & 70 & 0 & 1 & 0 & 0 & 66 \\
\hline
\end{tabular}

Anti-Hepatitis $B$ core antigen antibodies (HBcAb):

Detection of HBcAb was done using commercially available ELISA kit for the detection of antibodies to nucleocapsid antigen (core) of the HBV in human serum or plasma by enzyme immunoassay. Screening resulted in 449 positive donations (Table 6). There was no infection detected among volunteers in age range 18-20. The highest infection rate inside groups was in age ranges 51$60(21.96 \%)$ and age range 21-30 (3.67\%) was the lowest. 
Table 6: Age range of HBcAb positive among blood donors accepted for donation.

\begin{tabular}{cccrrr}
\hline Age range & Number & $\begin{array}{c}\text { \% in total } \\
\text { population }\end{array}$ & $\begin{array}{c}\text { HBcAb } \\
\text { positive } \\
\text { (n) }\end{array}$ & $\begin{array}{c}\text { \% infection } \\
\text { in total } \\
\text { population }\end{array}$ & $\begin{array}{c}\text { \% infection } \\
\text { inside the } \\
\text { age group }\end{array}$ \\
\hline $18-20$ & 408 & 6.091 & 0 & 0 & 0 \\
$21-30$ & 3384 & 50.523 & 135 & 1.8577 & 3.6725 \\
$31-40$ & 2021 & 30.173 & 157 & 2.1605 & 7.1267 \\
$41-50$ & 725 & 10.824 & 119 & 1.6375 & 15.1399 \\
$51-60$ & 160 & 2.389 & 38 & 0.5229 & 21.9653 \\
\hline Total & 6698 & 100 & 449 & 6.1786 & 6.1786 \\
\hline
\end{tabular}

Of these positive cases there were 70 cases positive for HBsAg. Cases positive to $\mathrm{HBc}-\mathrm{Ab}$ and positive to $\mathrm{HBV}$ -

DNA in the same time were 78. One case was coinfected with HCV (Table 7).

Table 7: Other markers associated with HBcAb positive blood donors accepted for donation.

\begin{tabular}{|l|c|c|c|c|c|c|c|}
\hline Positive to & HBsAg & HBcAb & HCV & HIV & RPR & HTLV & NAT \\
\hline HBcAb & 70 & 449 & 1 & 0 & 0 & 0 & 78 \\
\hline
\end{tabular}

Anti-Hepatitis $\mathrm{C}$ virus antibodies (HCV-Ab) test:

A detection hepatitis $\mathrm{C}$ virus antibody (HCV-Ab) was done using the commercially available $4^{\text {th }}$ generation kit.
Five cases were found to be positive for antibodies against HCV (Table 8). All cases were Saudi national aged 23, 36, 38,45 and 50 years old.

Table 8: Age range of HCV-Ab positive among blood donors accepted for donation.

\begin{tabular}{cccrrr}
\hline Age range & Number & $\begin{array}{c}\text { \% in total } \\
\text { population }\end{array}$ & $\begin{array}{c}\text { HBsAg } \\
\text { positive } \\
\text { (n) }\end{array}$ & $\begin{array}{c}\text { \% infection } \\
\text { in total } \\
\text { population }\end{array}$ & $\begin{array}{c}\text { \% infection } \\
\text { inside the } \\
\text { group }\end{array}$ \\
\hline $18-20$ & 408 & 6.09137 & 0 & 0 & 0 \\
$21-30$ & 3384 & 50.5225 & 1 & 0.0138 & 0.0272 \\
$31-40$ & 2021 & 30.1732 & 2 & 0.0275 & 0.0908 \\
$41-50$ & 725 & 10.8241 & 2 & 0.0275 & 0.2544 \\
$51-60$ & 160 & 2.38877 & 0 & 0 & 0 \\
\hline Total & 6698 & 100 & 5 & 0.0688 & 0.0688 \\
\hline
\end{tabular}

Of these positive cases there was one case (45 years old) positive for $\mathrm{HBcAb}$ and HBV-DNA in the same time and one case positive for HBV-DNA (Table 9).

Table 9: Other markers associated with HCV positive blood donors accepted for donation.

\begin{tabular}{|l|c|c|c|c|c|c|c|}
\hline Positive to & HBsAg & HBcAb & HCV & HIV & RPR & HTLV & NAT \\
\hline HCV & 0 & 1 & 5 & 0 & 0 & 0 & 2 \\
\hline
\end{tabular}

\section{DISCUSSION}

The group of viruses (hepatitis A, $\mathrm{B}, \mathrm{C}, \mathrm{D}$ and $\mathrm{E}$ ) that cause acute and/or chronic infection and inflammation of the liver gives rise to a major public health problem globally. Hepatitis B and C viruses are major causes of severe illness and death. The global burden of disease due to acute hepatitis $B$ and $C$ and to cancer and cirrhosis of the liver is high (about $2.7 \%$ of all deaths) and is forecast to become a higher ranked cause of death over the next two decades. (WHO, 2010).

Hepatitis B is a potentially lifethreatening liver infection caused by the hepatitis B virus. It is a major global health problem and the most serious type of viral hepatitis. It can cause chronic 
liver disease and puts people at high risk of death from cirrhosis of the liver and liver cancer. Worldwide, an estimated two billion people have been infected with the hepatitis $B$ virus and more than 240 million have chronic (long-term) liver infections. About 600,000 people die every year due to the acute or chronic consequences of hepatitis $B$. A vaccine against hepatitis $\mathrm{B}$ has been available since 1982. Hepatitis B vaccine is 95\% effective in preventing infection and its chronic consequences, and is the first vaccine against a major human cancer. Hepatitis B virus can cause an acute illness with symptoms that last several weeks, including yellowing of the skin and eyes (jaundice), dark urine, extreme fatigue, nausea, vomiting and abdominal pain. Hepatitis B is endemic in China and other parts of Asia. Most people in this region become infected with the hepatitis $B$ virus during childhood and $8-10 \%$ of the adult population is chronically infected. Liver cancer caused by hepatitis $\mathrm{B}$ is among the first three causes of death from cancer in men, and a major cause of cancer in women in this region (WHO, Fact sheet $\mathrm{N}^{\circ} 204,2012$ ).

In the present study, age range 21-30 years old constituted the largest population among blood donors. In addition majority of the donors were male and there were very little number of female donors during the period of this study. The percentage of non-Saudi donors was low. A similar study conducted on blood donors in Saudi Arabia by El-Hazmi (2004) also showed that the largest groups of donors were those at age range 20-29 years old and female donors were as low as $1.2 \%$ at year 2000 and declined to reach $0.7 \%$ by year 2002. Also El-Hamzi (El-Hazmi 2004) showed that the percentage of nonSaudi donors declined from $17.2 \%$ at year 2000 to reach 14.8 by year 2002 . Also Ankra-Badu et al. (2001) previously showed that the proportion of Saudi blood donors increased with the decrease in the non-Saudis blood donors.

In the present study blood donors were screened for the presence of HBsAg, anti-HBc, HCV-Ab, HCV-RNA and HBV-DNA. We found large number of anti-HBc carrier with or without HBsAg positivity. According to De Villa et al. (2003) HBcAb positivity with HBsAg negative status can reflect a number of situations: (1) it may indicate a false-positive result, so in the present study positive cases were confirmed using different detection kit; (2) it may represent past and currently healed infection, and this why we in the present study screened units for HBsAg positivity; and (3) it may constitute the sole marker of occult HBV infection, which is thus potentially transmissible, as has been demonstrated by contagion occurring through blood transfusion from donors who are only HBcAb (+) (Hoofnagle, Seeff et al. 1978).

In the present study it was found that HBsAg positive cases were low while $\mathrm{HBc}-\mathrm{Ab}$ positive cases were relatively high. Similar work done by Panhotra et al. (2005) on blood donors and showed that $1.9 \%$ were $\mathrm{HBsAg}$ positive alone, $3.2 \%$ were anti-HBc positive alone and $10.1 \%$ were both anti$\mathrm{HBc}$ and anti-HBsAg positive. In the current study we found only one case (0.02\%) positive for HBsAg alone which means that the presence of low HBsAg infection in Aseer region. It was previously shown shat there is a decline in hepatitis B viral infection in SouthWestern Saudi Arabia and it was attributed to the effectiveness and efficacy of the integration of hepatitis B vaccination into the extended program of immunization in KSA. The significant decline of HBV markers among unvaccinated Saudi adults indicated an indirect effect of other factors (for example health education and socioeconomic progress) on the prevalence and transmission of $\mathrm{HBV}$. In areas of 
high endemicity, the epidemiological characteristics HBV are modified significantly by the combination of HBV vaccination and other complimentary control strategies(Ayoola, Tobaigy et al. 2003).

Occurrence of HBsAg positivity among subpopulation was the lowest in 50-60 group, while it was zero in young population (group 18-20 years old). Vaccination against HBV was introduced 1989 for all infants at birth and in 1990 for school children (Al-Faleh 2003). This may be the most important factor responsible for the decline in $\mathrm{HBV}$ infection (Al-Faleh 2003).

A study done by El-Hazmi (ElHazmi 1989) conducted on male and female population in different provinces of Saudi Arabia. The overall prevalence of hepatitis B surface antigen (HBsAg) was high (16.7\%) and no significant difference was encountered between the rate in males and females. Different regions of Saudi Arabia showed a significantly variable prevalence of HBsAg. The eastern province had a prevalence of about $9 \%$ compared to the southwestern province where the prevalence was $25 \%$ in Jizan. The antibodies anti-HBs and anti-HBc were encountered in $30-67 \%$ of the individuals in different provinces, suggesting that a significant number of Saudis were already immune to HBsAg before they reached adulthood.

Presence of HBV-DNA in HBsAg positive samples was in nearly all cases except five samples. This indicates to how much these blood units are highly infective. Also, HBV-DNA was found in high percentage $(17.37 \%)$ of $\mathrm{HBC}-\mathrm{Ab}$ positive cases. This indicated that positive blood units for HBc-Ab should be discarded as it carries high possibility of infectivity. Current infection showing $\mathrm{HBsAg}$ and $\mathrm{HBc}-\mathrm{Ab}$ in the same time was high (15.59\%). In the time HBc-Ab positive cases with HBV-DNA negative is more than those cases with HBV-DNA positive, it still not secure to use these units in blood transfusion. The virus may be found in polymorhonuclear cells or other places other than serum or plasma used for the detection of HBV-DNA (Catterall, Murray-Lyon et al. 1994).

Previous studies since 1980s showed a high prevalence of HBV infection in Saudi Arabia ranging between $5-10 \%$ of the population varying from one region to another (Arya et al., 1985; Parande et al., 1986; Al-Faleh, 1988). The prevalence of HBsAg in children with ages of 1 to 10 years was about $7 \%$ in 1989, just before adding the $\mathrm{HBV}$ vaccine as the seventh primary immunogen of the Extended Program of Immunization (EPI) (Al-Faleh et al., 1992). This followed by vaccination of all children entering school in 1990 as a program launched by $\mathrm{MOH}$ (Al-Faleh et al., 1999).

In 1997, the efficacy of the hepatitis vaccination program was evaluated by means of a stratified cluster sampling technique in all 13 regions of KSA. This community-based study detected a decline of HBV infection among Saudi children up to the age of 12 years-from $7 \%$ in 1989 to $0.3 \%$ in 1997 (Al-Faleh et al., 1999). Children positive for $\mathrm{HBV}$ were found to have an HBVinfected father, mother, sisters or brothers. This indicates a major role for familial horizontal transmission of HBV in KSA. In the 1980s, a study of $\mathrm{MOH}$ blood donors showed that HBV infection averaged $5 \%$ to $10 \%$ (Al-Faleh, 1988). Screening of blood donors by Ministry of health showed that HBV infection in the year 2000 was at a prevalence rate of $3.2 \%$ and $5.9 \%$ among persons between 18-44 years old and over 50 years old respectively with an average of $3.25 \%$. The prevalence of HBV infection declined from $3.7 \%$ in year 1987 to1.7\% in year 2000 (Al-Faleh, 2003).

Hepatitis $C$ is a contagious liver disease that results from infection with the hepatitis $\mathrm{C}$ virus. It can range in 
severity from a mild illness lasting a few weeks to a serious, lifelong illness. The hepatitis $\mathrm{C}$ virus is usually spread when blood from an infected person enters the body of a susceptible person. It is among the most common viruses that infect the liver. Every year, 3-4 million people are infected with the hepatitis $\mathrm{C}$ virus. About 150 million people are chronically infected and at risk of developing liver cirrhosis and/or liver cancer. More than 350000 people die from hepatitis Crelated liver diseases every year (WHO, Fact sheet $\mathrm{N}^{\circ} 164,2012$ ).

The current study showed that HCV infection is very low $(0.067 \%)$ with complete absence of infection in age ranges 18-20 and 51-60 years old with only 2 cases having HCV-RNA positivity. Since the discovery of HCV in 1988 and introduction of diagnostic tests for this virus, data on HCV prevalence has accumulated in Saudi Arabia. In 1989, a baseline community randomized study in Jizan was done on children from the age of 1 to 10 years for prevalence of HCV. The average prevalence was calculated to be $0.87 \%$ (Al-Faleh et al., 1991). Another study in the same region in 1991 but on the adult population over the age of 10 years was done. The average prevalence was only $1.8 \%$, which increased with age, reaching 3.5\% in persons over 50 years (Al-Faleh et al., 1995). A study done on children aged 112 years in 13 regions of KSA in 1997, showed that the prevalence of HCV was only $0.04 \%$. Al-Faleh (2003) also analyzed Saudi blood donors from 1996 to 2001 at KKUH and demonstrated that the prevalence of $\mathrm{HCV}$ decreased steadily from $0.58 \%$ in 1996 to $0.28 \%$ in 2001, which is a decline among blood donors of more than $50 \%$ over 4 years.

\section{CONCLUSIONS}

Prevalence of HBsAg in Asser region is very low. The rate of $\mathrm{HBc}-\mathrm{Ab}$ in units of blood donation is relatively high. The presence of HBV-DNA in
$\mathrm{HBc}-\mathrm{Ab}$ positive donations make it risky for use. Vaccination program against $\mathrm{HBV}$ decreased the rate of $\mathrm{HBV}$ transmission. Infection rate of $\mathrm{HCV}$ is very low. Expected incidence of heptatocellular carcinoma due to infection with $\mathrm{HCV}$ is much lower than HBV.

\section{REFERENCES}

Al-Faleh F. Hepatitis B infection in Saudi Arabia Đ Clinical Review. Ann Saudi Med. 1988;8(6):474-480.

Al-Faleh FZ, Al-Jeffri M, Ramia S, AlRashed R, Arif M, Rezeig M, AlToraif I, Bakhsh M, Mishkhas A, Makki O, Al-Freihi H, Mirdad S, Aljumah AR, Yasin T, Al-Swailem AM, Ayoola A. Seroepidemiology of hepatitis B virus infection in Saudi children 8 years after a mass hepatitis B vaccination programme. J Infect.1999;38:167-170.

Al-Faleh FZ, Ayoola A, Arif M, et al. Seroepidemiology of hepatitis B virus infection in Saudi childrenÊ: A baseline survey for a mass vaccination against hepatitis $B J$ Infect.1992;24:197-206.

Al-Faleh FZ, Ayoola EA, Al-Jeffry M, et al. (1991). Prevalence of antibody to hepatitis $\mathrm{C}$ virus among Arabian childrenÊ: A community-based study. Hepatology. 14:215-218.

Al-Faleh FZ, Ramia S, Arif M, Ayoola EA, Al-Rashed RS, Al- Jeffry M, Hussain A, Al-Hazmi M. (1995). Profile of hepatitis $\mathrm{C}$ virus (HCV) and the possible modes of transmission of the virus in Jizan area, Kingdom of Saudi Arabia Đ A community-based study. Ann Trop \& Parasitol., 89(4):431-437.

Al-Faleh, F. Z. (2003). CHANGING PATTERN OF HEPATITIS VIRAL INFECTION IN SAUDI ARABIA IN THE LAST TWO DECADES . Ann Saudi Med 23 (5): 361-365 
Al-Faleh, F.Z. (2003). Changing pattern of hepatitis viral infection in Saudi Arabia in the last two decades. Ann Saudi Med 23 (6): 367-371.

Ankra-Badu, G.A., Ahmad, M., Sowayan, S., Bashawri, L. (2001). Demographic characteristics of seropositive donors in Al-Khobar. Ann Saudi Med 21 (1-2): 113-116.

Arya SC, Ashraf SJ, Parande CM, et al. (1985). Hepatitis B virus in Jizan, Saudi Arabia. J Med Virol. 17:267274.

Ayele, A. G. and S. Gebre-Selassie. (2013). Prevalence and Risk Factors of Hepatitis B and Hepatitis C Virus Infections among Patients with Chronic Liver Diseases in Public Hospitals in Addis Ababa, Ethiopia. SRN Tropical Medicine. Volume 2013:1-7.

Ayoola, A.E., Tobaigy, M.S., Gadour, M.O., Ahmad, B.S., Hamza, M.K., Ageel, A.M., (2003). The decline of hepatitis B viral infection in SouthWestern Saudi Arabia. Saudi Med J 24 (9): 991-995.

Bartosch, B. (2010). Hepatitis B and C Viruses and Hepatocellular Carcinoma Viruses, 2: 1504-1509

Beasley RP.; Hwang LY.; Lin CC. and Chien CS. (1981). Hepatocellular carcinoma and hepatitis B virus. A prospective study of 22707 men in Taiwan. Lancet 2:1129-1133.

Bill CA.; Summers J. Genomic DNA double-strand breaks are targets for hepadnaviral DNA integration. Proceedings of the National Academy of Sciences of the United States of America 2004; 101:11135-11140.

Bruix J, Barrera JM, Calvet X, Ercilla G, Costa J, Sanchez-Tapias JM, et al. (1989). Prevalence of antibodies to hepatitis $C$ virus in Spanish patients with hepatocellular carcinoma and hepatic cirrhosis. Lancet, 2:10041006.
Catterall, A.P., Murray-Lyon, I.M., Zuckerman, A.J., Harrison, T.J., (1994). Southern hybridisation analysis of HBV DNA in peripheral blood leucocytes and of different cell types: changes during the natural history and with interferonalpha therapy in patients with hepatitis $B$ virus infection. $\mathrm{J}$ Med Virol 43 (3): 269-275.

Catterall, A.P., Murray-Lyon, I.M., Zuckerman, A.J., Harrison, T.J., (1994). Southern hybridisation analysis of HBV DNA in peripheral blood leucocytes and of different cell types: changes during the natural history and with interferonalpha therapy in patients with hepatitis $\mathrm{B}$ virus infection. $\mathrm{J}$ Med Virol 43 (3): 269-275.

Colombo M, Kuo G, Choo QL, Donato MF, Del Ninno E, Tommasini M A, et al. (1989). Prevalence of antibodies to hepatitis $C$ virus in Italian patients with hepatocellular carcinoma. Lancet 2:1006-1008

De Villa, V.H., Chen, Y.S., Chen, C.L., (2003). Hepatitis B core antibodypositive grafts: recipient's risk. Transplantation 75(3 Suppl):49-53.

El-Hazmi, M.A. (1989). Hepatitis B virus in Saudi Arabia. J Trop Med Hyg, 92 (1): 56-61.

El-Hazmi, M.M., (2004). Prevalence of HBV, HCV, HIV-1, 2 and HTLVI/II infections among blood donors in a teaching hospital in the Central region of Saudi Arabia. Saudi Med J., 25(1): 26-33.

El-Serag, H.B. (2007). Epidemiology of hepatocellular carcinoma in USA. Hepatol. Res., 37 (Suppl. 2): S88-94.

Evans AA, O'Connell AP, Pugh JC, et al. (1998). Geographic variation in viral load among hepatitis B carriers with differing risks of hepatocellular carcinoma. Cancer Epidemiol Biomarkers. 7:559-565. 
Feitelson MA, Sun B, Satiroglu Tufan NLS, et al. Genetic mechanisms of hepatocarcinogenesis. Oncogene. 2002; 21:2593-2604.

Ferrari, C., G. Missale, C. Boni, and S. Urbani. 2003. Immunopathogenesis of hepatitis B. J. Hepatol. 39(Suppl. 1):S36S42.

Ferri C, Monti M, La Civita L, Longombardo G, Greco F, Pasero $\mathrm{G}$, et al. (1993). Infection of peripheral blood mononuclear cells by hepatitis $C$ virus in mixed cryoglobulinemia. Blood, 82:37013704.

Hoofnagle, J.H., 1990. Posttransfusion hepatitis B. Transfusion 30 (5): 384-386.

Ikeda K, Saitoh S, Koida I, et al. (1993). A multivariate analysis of risk factors for hepatocellular carcinogenesis: a prospective observation of 795 patients with viral and alcoholic cirrhosis. Hepatology., 18:47-53.

Kuniyoshi M, Nakamuta M, Sakai H, Enjoji M, Kinukawa N, Kotoh K, et al. Prevalence of hepatitis $\mathrm{B}$ or $\mathrm{C}$ virus infections in patients with non-Hodgkin's lymphoma. J Gastroenterol Hepatol 2001;16:215-219.

Laraba, A., G. Wadzali, B. Sunday, O. Abdulfatai, and S. Fatai, (2010). "Hepatitis C virus infection in Nigerians with chronic liver disease," The Internet Journal of Gastroenterology, 9:1

Lauer, G. M., and B. D. Walker. (2001). Hepatitis C virus infection. N. Engl. J. Med. 345:41-52.

London, W.T; K.A. McGlynn, Liver cancer, in: D. Schottenfeld, J.F. (2006). Fraumeni (Eds.), Cancer Epidemiology and Prevention, third ed., Oxford University Press, Inc., New York, 763-786.

Lu SN, Su WW, Yang SS, Chang TT, Cheng KS, Wu JC, Lin $\mathrm{HH}, \mathrm{Wu}$
SS, Lee CM, Changchien CS, Chen CJ, Sheu JC, et al. (2006). Secular trends and geographic variations of hepatitis $\mathrm{B}$ virus and hepatitis $\mathrm{C}$ virus-associated hepatocellular carcinoma in Taiwan. Int J. Cancer, 119:1946-52.

Montella M, Crispo A, de Bellis G, Izzo F, Frigeri F, Ronga D, et al. (2001). HCV and cancer: a case-control study in a high-endemic area. Liver 21:335-341.

Negri E, Little D, Boiocchi M, La Vecchia C, Franceschi S. (2004). B-cell non-Hodgkin's lymphoma and hepatitis $\mathrm{C}$ virus infection: a systematic review. Int J. Cancer, 111:1-8.

Panhotra, B.R., Al-Bahrani, A., UlHassan, Z. (2005). Epidemiology of antibody to hepatitis B core antigen screening among blood donors in Eastern Saudi Arabia. Need to replace the test by $\mathrm{HBV}$ DNA testing. Saudi Med J 26 (2), 270273.

Parande CM, Arya SC, Ashraf SJ. (1986). Hepatitis B virus among Saudichildren in Jizan, Saudi Arabia. Infection. 14:233-235.

Parkin DM, Bray F, Ferlay J, Pisani P. Global cancer statistics, 2002. CA Cancer J Clin 2005; 55:74-108.

Parkin DM, Bray FI, Devesa SS. (2001). Cancer burden in the year 2001. The global picture. Eur J Cancer. 37:S4-S66.

Pasquinelli C, Laure F, Chatenoud L, Beaurin G, Gazengel C, Bismuth H, et al. (1986). Hepatitis B virus DNA in mononuclear blood cells. A frequent event in hepatitis B surface antigen-positive and negative patients with acute and chronic liver disease. J Hepato,13:95-103.

Pawlotsky JM., Roudot-Thoraval F, Simmonds P, Mellor J, Ben Yahia $\mathrm{MB}$, Andre $\mathrm{C}$, et al. Extrahepatic immunologic manifestations in 
chronic hepatitis C and hepatitis C virus serotypes. (1995). Ann Intern Med 122:169-173.

Sato S, Fujiyama S, Tanaka M, Yamasaki K, Kuramoto I, Kawano S, Sato T, Mizuno

Schreiber, G.B., Busch, M.P., Kleinman, S.H., Korelitz, J.J. (1996). The risk of transfusion-transmitted viral infections. The Retrovirus Epidemiology Donor Study. N Engl J Med ,334 (26): 1685-1690.

Shi J, Zhu L, Liu S, Xie WF. (2005). A meta-analysis of case-control studies on the combined effect of hepatitis $B$ and $C$ virus infections in causing hepatocellular carcinoma in China. Br J Cancer 92:607-612.

Shi J, Zhu L, Liu S, Xie WF. (2005). A meta-analysis of case-control studies on the combined effect of hepatitis $B$ and $C$ virus infections in causing hepatocellular carcinoma in China. Br J Cancer, 92:607-612.

Shu-Chun Chuang a, Carlo La Vecchia b,c, (2009). Paolo Boffetta. Liver cancer: Descriptive epidemiology and risk factors other than HBV and HCV infection. Cancer Letters 286:9-14
Simonetti RG, Cottone M, Craxi A, Pagliaro L, Rapicetta M, Chionne $\mathrm{P}$, (1989). Prevalence of antibodies to hepatitis $\mathrm{C}$ virus in hepatocellular carcinoma. Lancet 2:1338.

Trends in hepatitis $\mathrm{C}$ virus infection Tsukuma H, Hiyama T, Tanaka S, et al. (1993). Risk factors for hepatocellular carcinoma among patients with chronic liver disease. N Engl J Med. 328:1797-1801.

WHO, (2010). Sixty-Third World Health Assembly. 25 March

World Health Organization: Hepatitis B Fact sheet $N^{\circ} 204$ July (2012). http://www.who.int/mediacentre/fa ctsheets/fs204/en/.

World Health Organization: Hepatitis C Fact sheet $\mathrm{N}^{\circ} 164$ July (2012). http://www.who.int/mediacentre/fa ctsheets/fs164/en/

Zarski JP, Bohn B, Bastie A, Pawlotsky JM, Baud M, Bost-Bezeaux F, Tran van Nhieu J, Seigneurin JM, Buffet C, Dhumeaux D. (1998). Characteristics of patients with dual infection by hepatitis $B$ and C viruses. J Hepatol 28:27-33. 